\section{Hong Kong A-2 Influenza Virus Infection among Swine during a Human Epidemic in Taiwan}

THE role of lower animals in the natural cycle of human strains of influenza virus transmission has been subjected to considerable speculation. With the possible exception of the report of Romvary et al. ${ }^{1}$, there are few, if any, satisfactorily authenticated cases of human influenza viral strains being isolated from naturally infected animals. That animals could be naturally infected was demonstrated when antibodies against the Asian A-2 strain were found in swine and horses after the 1957 pandemic $^{2}$.

Because of an accessible large porcine population on Taiwan ( 1959 census $-3,529,000$ pigs ; $14,350,000$ humans), an influenza surveillance study was recently initiated (June 1969) to determine whether pigs play a part in human infection. The study will continue for at least 12 months; but because of noteworthy results obtained during and immediately after an island-wide outbreak in humans (November 1969-January 1970), we are submitting this interim report.

Scra and nasal swabs are being obtained from apparently healthy 6 month old pigs from several Taiwan slaughterhouses. Sera were tested by haemagglutination-inhibition (HI) test against three antigens: A-2/Japan 305/1957 (A-2/Jap), A-2/Hong Kong/1968 (A-2/HK) and B/Lee/ 1940 (B/Lee). An HI titre of $1: 40$ or greater is considered positive.

For isolation studies swine nasal swab materials, obtained just before slaughter, were injected into primary monkey kidney tissue culture tubes, incubated, and observed for viral growth by use of the haemadsorption technique. The identity of viral jsolates was made by HI test, using reference influenza and parainfluenza antisera. Re-isolation attempts were made in tissue culture and fertile hens' eggs.

Table 1. APIEARANCE OF A-2/HONG KONG 1968 INFLCENZA ANTIBODY IN AND KECOVERY OF INFLLEXZA VIRUS FROM, TAIWAN PIGS

1969-1970 Antibodies against A-2/HK $\quad$ Isolation

results

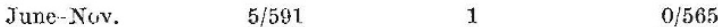

$\begin{array}{lrrr}\text { J)ecember } & 2 / 183 & 1 & 1 / 139\end{array}$

$\begin{array}{lrrr}\text { January } & 48 / 276 & 17 & 11 / 276 \\ \text { February } & 92 / 239 & 38 & 1 / 179\end{array}$

* Haemagglutination-inhibition titre of $1 ; 40$ or greater. All sera were negative against $\mathrm{A}-2 / \mathrm{J}$ apan $305 / 1957$ and $\mathrm{B} / \mathrm{L}$ ee $/ 1940$.

$\dagger$. 11 isolates tentatively identified as A-2/Hong Kong. Two identifications confirmed to date (see text).

Results are shown in Table 1. From June to November, 5 of 591 pigs were seropositive; all were at the minimal 1 : 40 endpoint. In December, January and February the seropositives were 2,48 and 92 respectively. The first viral isolate was obtained in December, followed by 11 in January and 1 in February. In other studies influenza A-2/HK isolates were obtained from humans in November and December 1969 during the epidemic occurring at that time in Taipei.

All sera were specific to the Hong Kong strain. There were no responses above the $1: 20$ level against A-2/Jap or B/Lee. In our tests all viruses were specific to $\mathrm{HK}$ antisera. We have re-isolated the virus from twelve of the original thirteen swabs in tissue culture tubes and/or fertile hens' eggs. All isolates have been sent to $\mathrm{Dr}$ Walter Dowdle of the WHO International Influenza Center for the Americas, National Communicable Disease Center, Atlanta, Georgia, for definite eharacterization. $\mathrm{He}$ has confirmed the first two isolates tested as being indistinguishable from prototype Hong Kong A-2 viruses. Representative seropositive swine sera have been sent to him for confirmatory laboratory testing, and we have sent him the original nasal swabs for independent reisolation. 'These results are pending. It is difficult to assess the significance of these findings at this early date. We are trying to gather data on when the influenza epidemic affected the areas of the pig farms. Preliminary indications are that the infection appeared in man before it appeared in swine. Further speculation on the role of the pig and other mammalian hosts in the epidemic and possible interepidemic cycle of human influenza will have to await subsequent reports.

I thank $\mathrm{Mr}$ Norman Chen and $\mathrm{Mr}$ G. S. Irving for technical assistance. This study was supported in part by the Bureau of Medicine and Surgery, Navy Department.

\section{W. D. KTNDIN}

US Naval Medical Research Unit No. 2,

Taipei, Taiwan, and

Department of Preventative Medicine,

University of Washington,

Seattle, Washington.

Received April 6, 1970.

I Romvary, J., Takatsy, Gy., Barb, K., and Farkas, E., Yature, 193, 907 (1962).

${ }^{2}$ Faplan, M. M., and Payne, A. M.-M., Bull. Wld Hlth Org., 20, 465 (1959).

\section{Replication of Murine and Feline RNA-containing C-type Viruses in Human Lymphoblastoid Cells}

MUrine and feline RNA-containing C-type viruses can replicate in human fibroblast-like cell monolayers with the establishment of virus shedding carrier cultures ${ }^{1-4}$. We describe here the establishment of virus shedding carrier cultures in human lymphoblastoid cell suspensions with a murine sareoma virus (MSV) and a feline sarcoma virus (FSV).

A virus shedding carrier culture of the Kirsten strain of MSV (Ki-MSV) in human adult fibroblast cells obtained from Dr V. Klement was maintained with Eagle's minimal essential medium (MEM) containing 10 per cent foctal calf serum (FCS) and antibiotics. A strain of FSV obtained from Dr M. Gardner ${ }^{5}$ was used to transform beagle embryo fibroblast cells. The transformed cells were cloned and a virus shedding carrier culture was established. These cells were maintained with MEM containing 10 per cent FCS and antibiotics.

Two human lymphoblastoid cell lines (Raji and HR1K) derived from Burkitt lymphomas were maintained with medium RPMI 1640 containing 20 per cent FCS and antibiotics. The Raji cells do not contain Epstein-Barr virus (EBV) particles ${ }^{6}$ whereas HRIK cells obtained from Dr J. Grace, jun., do produce varying amounts of EBV particles?. Tho Raji and HRlK cells were passaged by seeding $50 \mathrm{ml}$. of a cell suspension containing $2 \times 10^{5}$ $3 \times 10^{5}$ cells $/ \mathrm{ml}$. in C-32 fluid ounce bottles. The cultures were incubated in a horizontal position at $37^{\circ} \mathrm{C}$ in an atmosphere of air and 3 per cent $\mathrm{CO}_{2}$. Medium was added after 4 days to bring the volume to $200 \mathrm{ml}$. BY day 7 the cell density had reached a stationary level of $1.5 \times 10^{6}-2.0 \times 10^{6}$ cells per ml. with 95 per cent viability as determined by trypan blue exclusion.

The virus containing media from Ki-MSV infected human fibroblast cultures and FSV infected canine cultures wore clarified at $10,000 \mathrm{~g}$ for $20 \mathrm{~min}$, and the virus was pelleted at $53,700 \mathrm{~g}$ for $2 \mathrm{~h}$. The pellets were resuspended in medium to give a final concentration of 100 times. Human lymphoblastoid cells $\left(10^{7}\right.$ viable cells $)$ were resuspended in $1.0 \mathrm{ml}$. of the virus suspension and infected on a magnetic stirrer at $37^{\circ} \mathrm{C}$ under $\mathrm{CO}_{2}$ for $2 \mathrm{~h}$. The cells were washed twice and were resuspended in approximately $20 \mathrm{ml}$. of medium to give a viable cell concentration of $5 \times 10^{5}$ cells $/ \mathrm{ml}$. The cultures were incubated and medium was added at intervals to maintain the cell density at a maximum level of approximately 